\title{
DESIGN HORIZONTAL AXIS WIND TURBINE WITH THREE BLADES
}

\author{
Basuki Winarno, Imam Basuki, Ali Safi’i
}

\begin{abstract}
The use of energy, especially electrical energy in need once by the public. Lots of alternative energy in Indonesia that can be utilized to generate electrical energy. One of them is wind energy. Wind energy is easy to get especially in coastal areas. Electrical energy is not solely produced by nature. So to take advantage of the wind in need of a tool that can work and produce electricity well. Tools that can be used are windmills. One of them is Horizontal Axis Wind Turbine with Three Blade which will drive the gear box and then rotate the generator. In this wind turbine the material used to make the blade is mindi wood. The wood is quite strong, lightweight and easily obtained by size. The experimental results at a wind speed of $4-6 \mathrm{~m} / \mathrm{s}$ with an angle of $60^{\circ}$ at rpm gain on a generator of about 1300 with an output of 15.92VDC
\end{abstract}

Keywords : Wind Energy, HAWT, Blade, Gear box.

\section{INTRODUCTION}

$\mathrm{P}$ ower Plant is a power plant that uses wind as the main energy source. At this plant can convert wind energy into electrical energy through wind turbine and windmill. Wind turbines are divided into two types, namely Horizontal Axis Wind Turbine (HAWT) and Vertical Axis Wind Turbine (VAWT)

HAWT is a wind turbine that moves with a horizontal axis. As for VAWT wind turbines moving with a vetical axle At (HAWT) and (VAWT) there are other components, ranging from Turbine, Gear Box, Generator, Buck boost, Battery, Inverter and others.

In commonly used HAWT blade turbines are two, three, or more than three. In wind turbine tadpoles the three values of torque produced are large, but have a low rpm. While the wind turbine tadpoles a lot of torque generated small, but high rpm. As more blades are used, the thinner the blade is used. The material for making the blade should be a bit light and strong, such as Mindi Wood or resin to print blades with fiber fibers to reinforce blade shapes.

Basuki Winarno is with Departement of Electrical Engineering State Polytechnic of Madiun, Madiun, Indonesia (corresponding author provide phone +62 351 452970; email basuki@pnm.ac.id)

Imam Basuki is with Departement of automotive Engineering State Polytechnic of Madiun, Madiun, Indonesia (corresponding author provide phone :+62 351452970 ; email imam yb@pnm.ac.id)

Ali Safi'I is with Departement of Electrical Engineering State Polytechnic of Madiun, Madiun, Indonesia (corresponding author provide phone +62 351 452970; email alisyafii260@gmail.com)
The weight of the blade also affects the torque to be generated and the cross-sectional area will also affect the energy generated from the wind energy displacement that will make the blade spin. Sensor placement is at an estimated distance of $300 \mathrm{~cm}$ or 3 meters from sea level, on the prototype indicator there are 3 states that are safe, danger and out of reach.

\section{RELATED WORK}

[1] Ramdani Ahmad Subekti. Wind Turbine Horizontal Turbine Design Capacity 1000 watts. Diponegoro University (2014), designed the Horizontal Axis Wind Turbine (HAWT) design using three blades. But the angle in use can not be in the fox. The materials used to make the blade, using resin which is then printed according to the desired blade.

[2] Hendra Wijanarko. Design of Thermal Horizontal Wind Turbine Power Plant. State Polytechnic of Madiun (2016). Materials used to make blade from PVC. The design of the equipment works without taking into account the size of the length and produce very little power.

\section{SISTEM DEVELOPMENT}

\section{A. Design}

The material used as a blade must be strong so as not to be easily broken to get a large enough torque, while the gear box cultivated has a minimal frictional style. Specifications the manufacture of turbine blades and gear boxes is shown in table 1 .

Table 1. Spesification Blade

\begin{tabular}{|c|c|c|c|c|}
\hline Type & $\begin{array}{l}\text { Base } \\
(\mathrm{cm})\end{array}$ & $\begin{array}{l}\text { Middle } \\
(\mathrm{cm})\end{array}$ & $\begin{array}{l}\text { Tip } \\
\text { base } \\
(\mathrm{cm})\end{array}$ & $\begin{array}{l}\text { Total } \\
\text { length } \\
(\mathrm{cm})\end{array}$ \\
\hline Blade 1 & 20 & 95 & 10 & 125 \\
\hline Blade 2 & 20 & 100 & 10 & 130 \\
\hline
\end{tabular}

Blade material made from balsa wood. Because it is light and strong and easy to form. The Blade Length is roughly about 1.25 for each blade. The height of the pole is made of iron with a height of about 2 meters, shown in figure 1. 


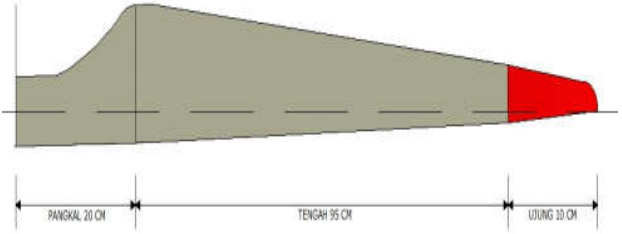

Fig.1 Blade design.

The blade design uses 2 types, for the first blade slightly pointy and for the second blade the width of the cross section is larger than the first blade. For the design of the blade is almost the same as the wing system on the aircraft in terms of aerodynamics shown in Figure 2

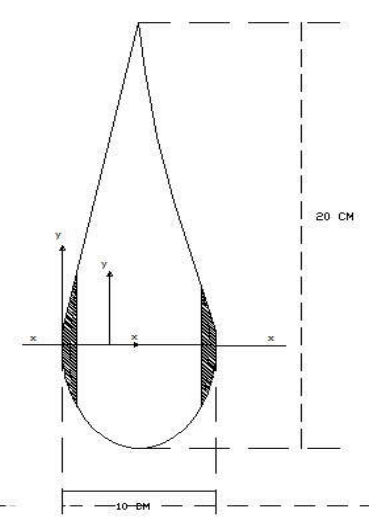

Fig. 2. Blade Vertically

All design of wind power plants with horizontal axis using a buffer pole of about $6 \mathrm{~m}$ with three-legged triangle-shaped tower shown in Figure 3.

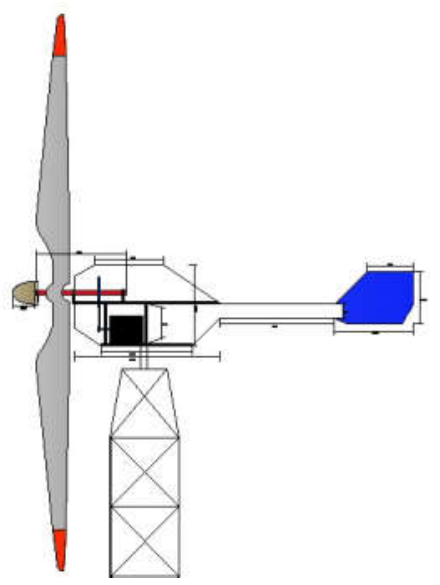

Fig.3. Desain HAWT

\section{B. Equipment work system}

The equipment works by obtaining wind energy that will rotate the horizontal wind turbine, then it will rotate the gear box that has been connected to the generator. Generator generated voltage is used as input buck boost converter. Next is used for charging accumulator connected with inverter. The inverted inverter serves to change the voltage of $12 \mathrm{VDC}-220 \mathrm{VAC}$ which then connect to the load.

\section{PERFORMANCE EVALUATION AND RESULT}

After measuring, and designing tools that have been made, then the next stage is to test the tool intended to know work or not the tool. Wind turbine test is using the wind that is housed in the building M. Noah 4th floor State Polytechnic Madiun. To measure wind speed in use Anemometer and to measure Rpm in use Tachometer. After the testing phase of the tool is done, it needs to be evaluated around the weaknesses and shortcomings of the tools that have been designed by analyzing the performance of the tools that have been tested.

The first test is performed to determine the rpm in wind turbine, rpm on gear box and rpm in the generator. Once obtained the data, the next step is to make Horizontal Axis Wind Turbine which is tadpole three with materials and equipment that have been available.

The steps that need to be done are:

1. Cut the wood according to the design with the length of $125 \mathrm{~cm}$ and $130 \mathrm{~cm}$ with a width of $10 \mathrm{~cm}$ and 3.5 $\mathrm{cm}$ thick.

2. Cut and weld the size of elbow and size weld to make the blade tower.

3. Cut an iron blat with a diameter of $20 \mathrm{~cm}$ to make the axle on the blade.

4. Cut the iron elbow to place the turbine ass, gear box and generator stack and combine with welding with size $30 \times 60 \mathrm{~cm}$.

5. Cut the iron beam $70 \mathrm{~cm}$ and iron plate $30 \times 30$ with triangular shape to make the wind turbine tail.

6. Cut the iron concrete ester with a diameter of $6 \mathrm{~mm}$ stack with size $40 \times 40 \mathrm{~cm}$ then cast to make a base or a tower seat turbine.

7. Horizontal wind turbine component has been completed.

Once the blade is made and ready for installation is shown on the Figure 4.

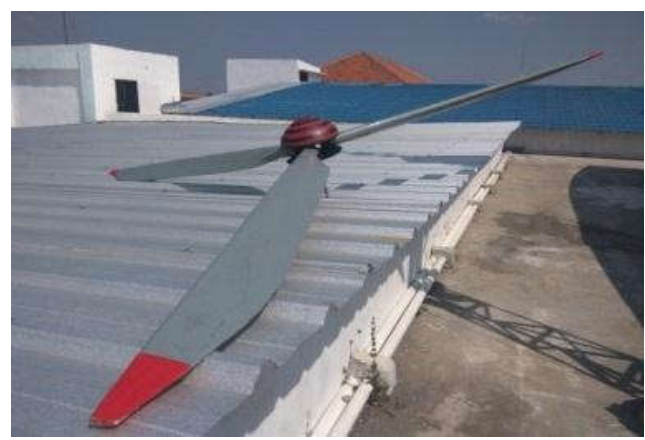

Fig.4. Blade is ready to install

Assembly steps after all horizontal wind turbine components have been completed.

1. Prepare a Tachometer to calculate Rpm, Anemometer to measure wind speed and Avometer to measure output on the generator.

2. Pair the blade on where the blade has been made and set the appropriate corner of the test.

3. Pair the generator into the generator holder that has been made. 
4. Place and unite the supporting pole with the nut and bolt then combine with the cast mat that has been made.

5. Combine turbines, gear boxes and generators into one piece and install on top of the tower that has been in stacking.

6. Measure and calculate the output of turbine generator and rpm output.

Blade installation can be done according to the desired angle at the time of data retrieval. In the picture above use a second blade with an angle of $60^{\circ}$ on each blade. For installation of gearbox and generator is done which has been in add rectifier for generator from $\mathrm{AC}$ to $\mathrm{DC}$ voltage shown in figure 5.

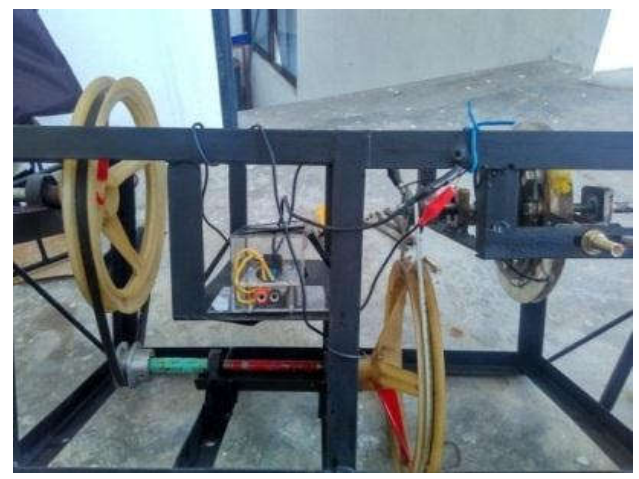

Fig.5. Gear box and generator

The installation of a blade on the supporting pole that has been connected to the gear box and generator is shown in figure 6 .

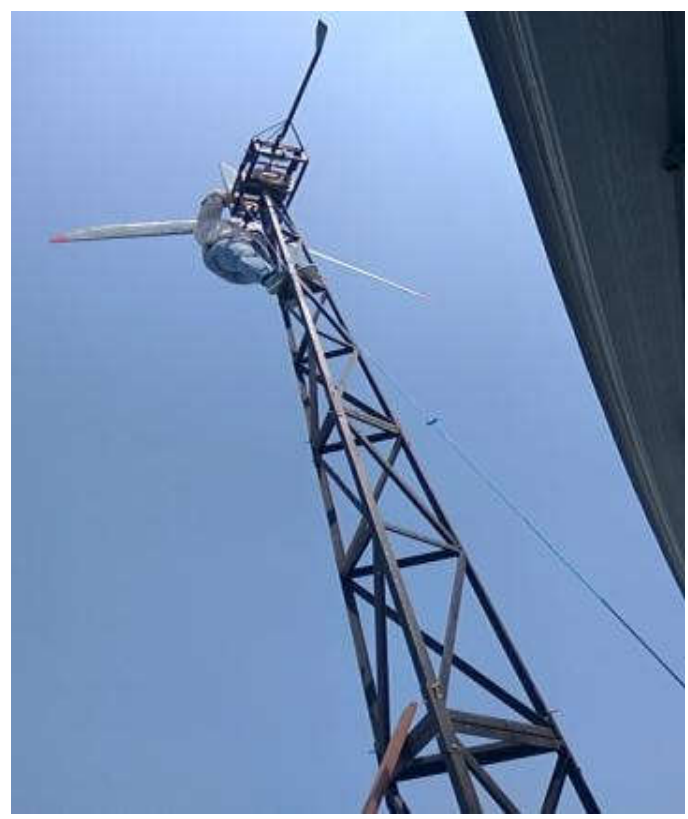

Fig.6. Installation of HAWT on pole.

After HAWT is installed, a blade 1 test is performed with a specification of the 575 sectional area and weighs about 750 grams for each blade. Testing is done by changing angle $30^{\circ}, 45^{\circ}$, and $60^{\circ}$ conducted at $12.00-15.00$ WIB shown in table 2 .
Table 2. Blade test data 1

\begin{tabular}{|c|c|c|c|c|c|}
\hline Sudut & $\begin{array}{c}\text { Kecepatan } \\
\text { Angin } \\
(\mathrm{m} / \mathrm{s})\end{array}$ & $\begin{array}{c}\text { Kecepatan } \\
\text { Turbin } \\
(\text { Rpm })\end{array}$ & $\begin{array}{c}\text { Kecepatan } \\
\text { Gear box } \\
(\text { Rpm })\end{array}$ & $\begin{array}{c}\text { Kecepatan } \\
\text { Generator } \\
(\text { Rpm })\end{array}$ & $\begin{array}{c}\text { Output } \\
\text { Generator } \\
(\mathrm{V})\end{array}$ \\
\hline \multirow{5}{*}{$60^{\circ}$} & $3,4-4,9$ & 20 & 140 & 980 & 5,43 \\
\cline { 2 - 6 } & $3,3-4,2$ & 18 & 132 & 924 & 5,11 \\
\cline { 2 - 6 } & $4,8-5,1$ & 22 & 155 & 1085 & 7,31 \\
\cline { 2 - 6 } & $4,0-5,5$ & 25 & 175 & 1225 & 9,72 \\
\hline \multirow{5}{*}{$45^{\circ}$} & $3,5-4,9$ & 18 & 130 & 910 & 4,53 \\
\cline { 2 - 6 } & $3,3-4,0$ & 17 & 127 & 889 & 4,11 \\
\cline { 2 - 6 } & $4,8-5,5$ & 23 & 165 & 1155 & 7,68 \\
\cline { 2 - 6 } & $3,3-3,5$ & 16 & 122 & 854 & 2,21 \\
\hline \multirow{5}{*}{$30^{\circ}$} & $3,2-3,9$ & 17 & 124 & 869 & 3,68 \\
\cline { 2 - 6 } & $3,3-3,6$ & 16 & 120 & 840 & 2,62 \\
\cline { 2 - 6 } & $3,8-5,0$ & 20 & 140 & 1029 & 6,44 \\
\cline { 2 - 6 } & $4,2-5,8$ & 22 & 157 & 1099 & 7.23 \\
\hline
\end{tabular}

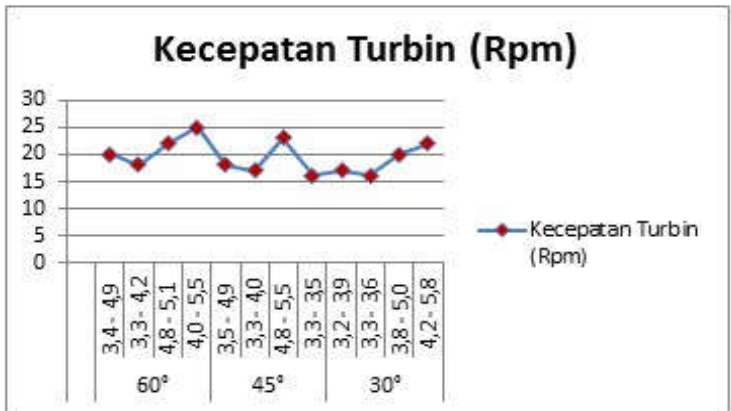

Fig.7. Blade 1 Turbine

Figure 7, the results of the graph with the second blade, showing the value up and down due to different wind speeds with a minimum wind speed of $3.2 \mathrm{~m} / \mathrm{s}$ and a maximum of $5.8 \mathrm{~m} / \mathrm{s}$

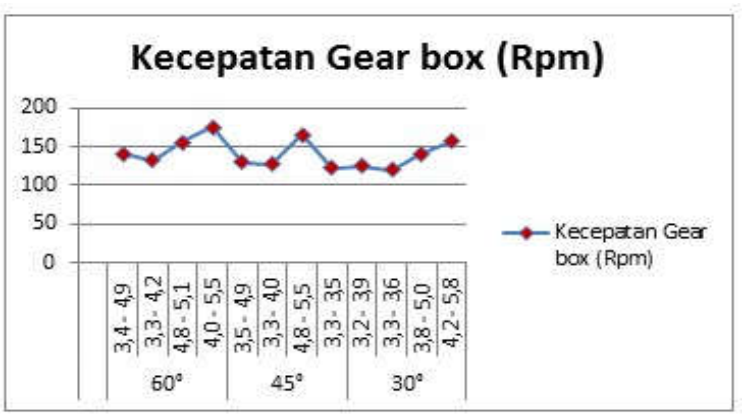

Fig.8. Blade 1 Gearbox

Figure 8 , the gearbox speed graph using blade 1 shows the speed increase of the lower turbine in folded gear box.

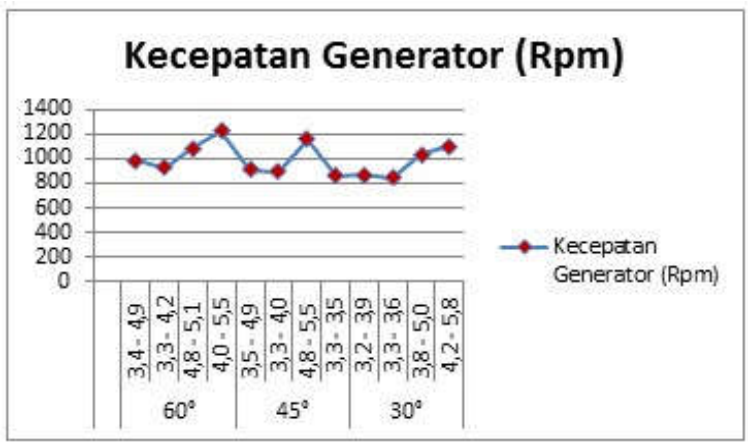

Fig.9. Blade 1 Generator 


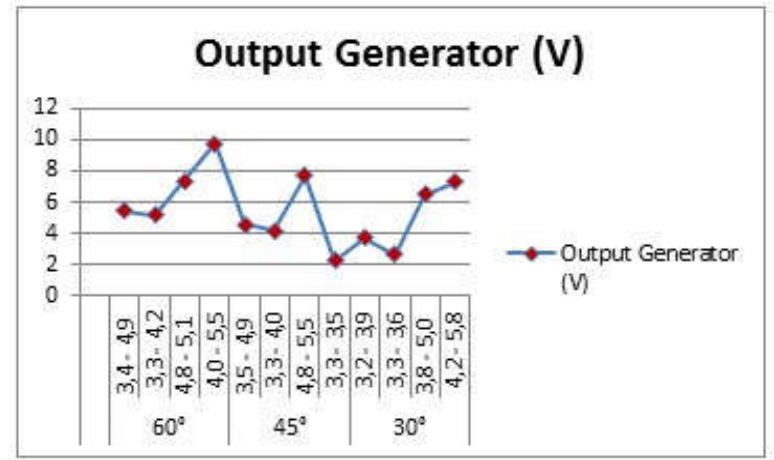

Fig.10. Blade 1 Output Generator

Figs. 9 and 10 show that the generator output results up and down due to wind differences. In this experiment, the highest value of generator output is about 10VDC in experiment using angle $60^{\circ}$. In experiments using blade 1 , the highest generator output value is about $10 \mathrm{VDC}$ and at least about 2 VDC. Because it affects the existing wind energy, as well as the cross-sectional area of blade and weight of blade 1 .

In the second test using blade 2 with the specification of the cross-sectional area of 1150 weighing about 1500 grams for each blade. Testing using angle $30^{\circ}, 45^{\circ}, 60^{\circ}$. Generator is used as wind turbine load conducted at 12.00 - 15.00 WIB shown in table 3.

Table 3. Blade test data 2

\begin{tabular}{|c|c|c|c|c|c|}
\hline \multirow{3}{*}{ Sudut } & $\begin{array}{c}\text { Kecepatan } \\
\text { Angin (m/s) }\end{array}$ & $\begin{array}{c}\text { Kecepatan } \\
\text { Turbin } \\
(\text { Rpm) }\end{array}$ & $\begin{array}{c}\text { Kecepatan } \\
\text { Gear box } \\
(\text { Rpm) }\end{array}$ & $\begin{array}{c}\text { Kecepatan } \\
\text { Generator } \\
(\text { Rpm) }\end{array}$ & $\begin{array}{c}\text { Output } \\
\text { Generator } \\
(\mathrm{V})\end{array}$ \\
\hline \multirow{5}{*}{$60^{\circ}$} & $4,6-5,8$ & 25 & 178 & 1246 & 14,21 \\
\cline { 2 - 6 } & $4,8-5,0$ & 21 & 152 & 1064 & 8,31 \\
\cline { 2 - 6 } & $3,3-4,5$ & 19 & 137 & 959 & 5,43 \\
\cline { 2 - 6 } & $3,2-4,0$ & 17 & 123 & 861 & 4,13 \\
\hline \multirow{5}{*}{$45^{\circ}$} & $4,8-5,5$ & 23 & 165 & 1155 & 12,63 \\
\cline { 2 - 6 } & $4,0-4,5$ & 20 & 143 & 1001 & 7,22 \\
\cline { 2 - 6 } & $3,5-3,8$ & 21 & 147 & 1029 & 6,37 \\
\cline { 2 - 6 } & $4,2-6,5$ & 28 & 196 & 1372 & 15,92 \\
\hline \multirow{5}{*}{$30^{\circ}$} & $4,2-4,8$ & 19 & 135 & 945 & 5,11 \\
\cline { 2 - 6 } & $3,8-4,0$ & 16 & 118 & 826 & 4,55 \\
\cline { 2 - 6 } & $3,0-3,6$ & 14 & 98 & 686 & 3,11 \\
\cline { 2 - 6 } & $4,0-4,3$ & 18 & 130 & 910 & 4,98 \\
\hline
\end{tabular}

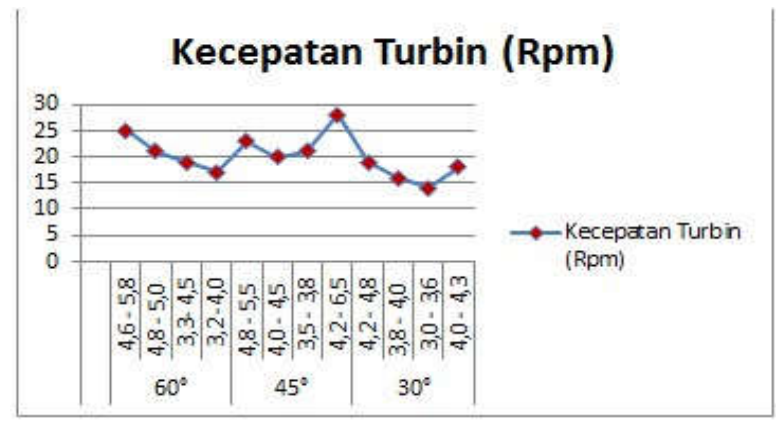

Fig.11. Blade 2 Turbine

The result of the graph with balde 2 shows the value up and down due to different wind speeds with a minimum wind speed of $3.0 \mathrm{~m} / \mathrm{s}$ and a maximum of $6.5 \mathrm{~m} / \mathrm{s}$.

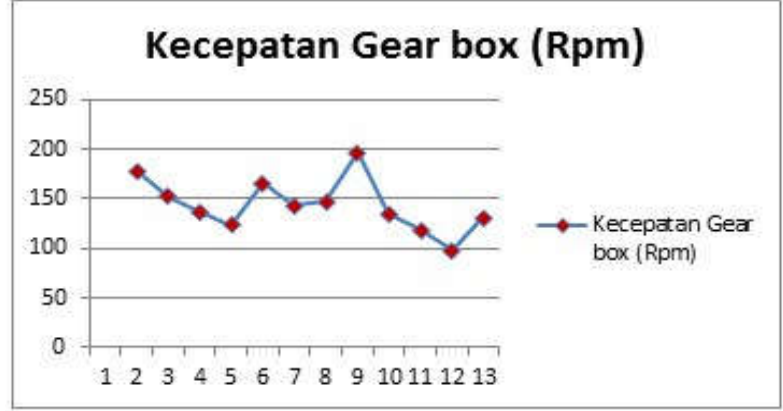

Fig.12. Blade 2 gearbox

Graph of gear box speed using blade 2 shows the speed increase of the turbine that is folded in the gear box

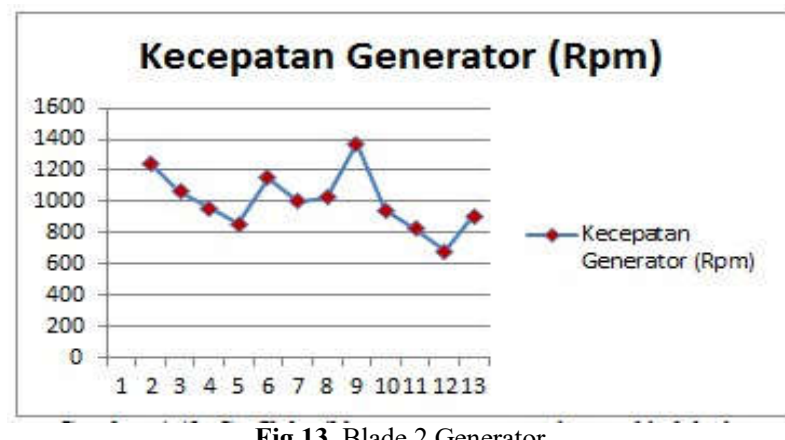

Fig.13. Blade 2 Generator

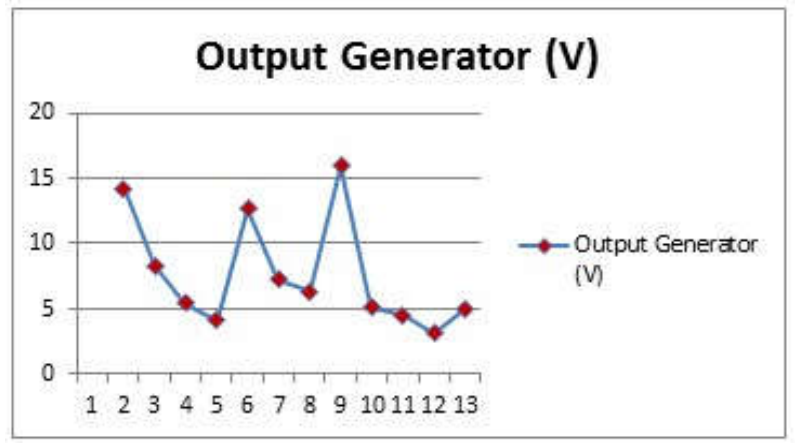

Fig.14. Blade 2 Output Generator

Figs. 13 and 14 show generator output results up and down due to wind differences. In this experiment, we get the highest value of generator output around 15VDC in experiment using angle $60^{\circ}$. The results of the second experiment using blade 2 results are better than blade 1 , this is because the sectional area and weight of blade 2 is wider and heavier than blade 1 with an average wind speed of 3-6 m/s so that the generator output is larger from the first try 


\section{CONCLUSION}

Based on the results of testing and analysis conducted on the design HAWT it can be concluded:

1. Designing a three tiered Horizontal Wind Turbine using material from mindi wood to create the blade.

2. Create a horizontal wind turbine buffer with an angle of iron with a height of $6 \mathrm{~m}$.

3. The best result is at wind speed $\pm 6 \mathrm{~m} / \mathrm{s}$ using second blade with angle $60 \square$ obtained rpm at generator \pm 1300 with generator output $\pm 15,92$ VDC.

4. Lowest result with angle $30 \square$ with first blade wind speed $\pm 6 \mathrm{~m} / \mathrm{s}$ got rpm generator \pm 1000 with output generator $\pm 7 \mathrm{VDC}$

While to improve this research can be done HAWT development on the protection system, automatic angle modifiers that can be done automatically, the use of lighter blade material but has a large torque and gear box system that uses a lighter fanbelt but the torque is large enough and rpmnya higher. 


\section{REFERENCES}

[1] Desna, H. Optimasi Desain Blade Pada Turbin Angin Poros Horizontal untuk memenuhi Kebutuhan Daya Pada Squid Fishing Vessels,; Institut Teknologi 10 November. Surabaya, 2008

[2] Ramdani, A. dkk. Rancang Bangun Turbin Angin Sumbu Horizontal Kapasitas 1000 watt, Universitas Diponegoro. Semarang. 2009

[3] Hendra, W. Rancang Bangun Pembangkit Listrik Turbine Angin Horizontal,; Politeknik Negeri Madiun. Madiun, 2016 